\begin{abstract}
Shapsugova M.D.
Candidate of Legal Sciences, Associate Professor

Senior Researcher of the Sector of Business and Corporate Law, Institute of State and Law of the

Russian Academy of Sciences
\end{abstract}

\title{
FAVORABLE INVESTMENT CLIMATE IN DIGITAL SPACE
}

\begin{abstract}
Digital spaces in the fourth industrial revolution have become the most critical environment for integrating production goods. International and interregional economic and investment transactions carried out by economic entities create common digital spaces.

Such spaces can be universal and regional. Work on the creation of universal digital spaces is being carried out at the UN level. Regional digital spaces are being formed in the EU and the EAEU.

The trusted environment formed by the digital space increases investment attractiveness and allows economic entities to increase the speed of transactions.

The formation of an environment of trust requires a unique infrastructure: secure communication channels, means of confirming identification, databases, electronic document management.

Trust environments are divided into centralized and decentralized. Their specific features and differences are discussed in this article.

The problems that arise during the interstate interaction of economic entities, such as the integration of databases, storage of information and protection of personal data, the formation of the same attributes of an electronic document, and identification, are identified.

The article also examines the impact of digitalization on the investment attractiveness of the region. It has been determined that digital transformation affects the investment climate and investment attractiveness both directly and indirectly. With an indirect influence, investment attractiveness increases due to the development of digital infrastructure, an increase in the speed of transactions between the private and public sectors, and increased transparency of interaction with government agencies. Also, special investment instruments are being created.
\end{abstract}

Keywords: digital space, digital platform, digitalization, investment attractiveness, investment climate, investments, InvestTech, identification, integration

\section{Introduction}

Decree of the President of the Russian Federation of 09.05.2017 N 203 approved the Strategy for the Development of the Information Society in the Russian Federation for 20172030 (from now on referred to as the Strategy) introduces the concepts of the digital economy and the ecosystem of the digital economy.

Under the Strategy, the following signs of the digital economy can be distinguished: digitized data become one of the main factors of production, their processing is carried out in larger volumes than in the traditional economic system, which allows them to be used more rationally, and ultimately this process leads to an increase in the efficiency of economic activities, production, operation of infrastructure, movement of goods, works of services based on digital platforms. 
The barrier-free movement of investments, goods, and services requires the formation of a single digital space.

Methods

Digital spaces began to appear relatively recently, representing a qualitatively new manifestation of social interaction. In connection with this, their research was carried out using the phenomenologic method.

The classification method was used to determine the classification and delimitation criterion of universal and regional digital spaces and centralized and decentralized spaces of trust.

The induction and deduction methods and the method of abstraction were used to develop the categorical apparatus.

The comparative method was applied to analyze Russian, foreign, and universal experience in building digital spaces.

Results

The study revealed the impact of digital spaces on investment attractiveness. The main problems of the formation of digital spaces are determined; their creation is investigated. Conclusions were formulated about the need to develop digital spaces to create a favorable investment climate.

Discussion

A common digital space is built based on a digital platform that connects the subjects of interaction through communication channels.

Common economic space in terms of digitalization is formed based on digital spaces of trust, which aggregate all society's productive forces.

Common digital space is based on digitalization of markets, digitalization of governance, transforming relations in the private and public sector, the digital transformation of the economy, the emergence of a segment of digital goods, assets, and services.

Development of digital spaces of trust provides tons of market subjects of many new features due to several factors:

- An extensive spheres $\mathrm{s}$ application: trade, transportation, finance, and to facilitate interaction with the state government

- Contractions rate and expenses on the transaction, including the international, simplifying the investment process

- raising the level of reliability of data, thereby increasing the confidence of participants in the interaction

- reductions administrative barriers and corruption that leads to the improvement of the investment climate

- simplified customs control and monitoring of foreign trade activities.

The problems arising in the development of digital spaces of trust include digital inequality, platform integration, compatibility, technological and technical solutions, the software used in different countries, legal problems, electronic documents signing, and the identity of the subject in the digital space official authorities, the presence of the necessary document attributes, and identification and authentication in the national and cross-border exchange of information, recognition of the identification method in another state, problems in the differences in information protection standards, personal data, legal obstacles to their exchange, as well as problems in the differences in requirements for documents, which entails the need for development and general details of documents). 
The study of spaces of trust requires their scientific classification.

Spaces of trust can be subdivided into national and transboundary based on territorial coverage.

The formation of spaces of trust accelerates the processes of globalization, promotes integration processes.

Interacting subjects in the digital environment are built on the base principle of trust.

When building transnational digital spaces, trust between interaction subjects is established and maintained through mutual recognition of trust services by different jurisdictions [1].

Trust is a public function. It can not be built solely on technology. At the same time, such technology can significantly increase the level of trust in public interactions.

A prerequisite for trust in a single digital space is its security and sustainability.

Trust the first (functional) order, and the second (legal) order is distinguished. The firstorder trust is formed through communication networks, data processing, and various services. Confidence second order is based on the recognition and legally second significance and results of using these services confidence subjects interaction and does not depend on the specific functional services, nor the specific technical data [1].

Models construct of digital spaces can be centralized and decentralized.

The centralized model of building an infrastructure of trust is a neutral international environment for individual countries and their associations, stable with political, economic, social, and other influences and interests of its participants. Trust is built in a centralized model on public relations institutionalized by the corresponding trust infrastructure participants. The centralized model is based on all its participants' fulfillment of the same agreed Requirements when conducting periodic independent audits of authorized operators of trust services [1]. In a centralized system, the trust provided by the agreements between the member states, based on which is created is necessary infrastructures and trust.

The centralized model has a number of advantages. In particular, it rests on traditional institutions of identification and electronic interaction, promotes public-private partnership within the framework of trust infrastructure, and is easily scalable [1].

The most popular technology, implementing decentralized models of trust infrastructure architecture, is blockchain -technology ( blockchain ). It is characterized by anonymity and has some peculiarities: the blockchain system's nodes are uncontrollable and equal, supported by mathematical, technological, and not organizational (as in a centralized model) methods [1].

Obstacles to the creation of confidence spaces appear digitally inequalities of the problems of identification of subjects. In interstate interactions in the digital environment, identifying subjects is most acute since, on the one hand, the unification of identifying features at the state level is required. On the other hand, the integration of databases is required, which inevitably creates the problem of storing and leaking personal data subjects. Creating unified identification systems can be solved by combining databases and data exchange in various countries. An example is a system for identifying participants in foreign economic activity on the territory of the EAEU, within the framework of which a 17- digit code will be formed based on the TIN assigned in the member state. The specified identification system was created, taking into account its integration with the EORI system (the EU system).

The substantive similarity of the tasks for the formation of the EDS in different regions of the world and the need for their subsequent integration within the global economy actualize the problem of developing the basic architectures of the digital economy based on the experience gained primarily within the framework of the UN Center for Trade Facilitation and Electronic 
Business (UN / CEFACT), including on the topics of the formation and functioning of a single window and a cross-border space of trust, as a natural development of these topics in the direction of the ETSP [2, p. 12].

At the universal level within the UN framework

- UN / EDIFACT - Electronic Data Interchange for Administration, Commerce, and Transport - UN Regulations for Electronic Data Interchange in Administration, Commerce, and Transport, published as an international standard ISO 9735;

- UN Trade Data Elements Directory - a directory of foreign trade data elements of an international standard for electronic data interchange of UN rules published as an international standard ISO 73725;

- UN Layout Key For Trade Documents, published as international standard ISO 6422;

- Core Component Library, UNCC ( Core Component Library, version 08B), part of the published international standard ISO 17000.

The legal barriers to the digital economy's development include the lack of necessary definitions in regulations, the need for legally significant actions to confirm identity remotely, and the recognition of electronic documents [3].

The state creates an environment of trust for fiscal and control purposes.

Business needs such an environment for the conclusion, execution, and termination of contracts, for the performance of legally significant business entities' actions.

Trust in the digital environment is provided by trusted certifying centers, digital signature, the legal force of electronic documents in [4, p. 15], and the identification of subjects in the system and confirmation of their authority.

Ensuring the technical compatibility of databases as an element of the digital environment presupposes the same document attributes.

Development of paperless trade promoted and the following events:

1. The adoption of the European Commission Strategy for the Single Digital Market ( the Digital Single Market (the DSM) Strategy ) (Regulation number 910/2014 7)

2. In 2007, Russia was offered the project "Organization of cross-border electronic interaction using the electronic digital signature."

3. Creating a Pan-Asian alliance and for digital commerce (PAA)

Within the EAEU, serious work is also underway to organize the member states' single digital space. The following primary documents were adopted:

- Protocol on Information and Communication Technologies and Information Interaction within the Eurasian Economic Union

- By the Treaty on the EAEU, a general program has been underway for several years to create an Integrated Information System of the Union (IISS),

- The decision of the Board of the Eurasian Economic Commission of September 27, 2016 N. 105 "On the Strategy for the Development of a Cross-Border Space of Trust"

- The decision of the Council of the Eurasian Economic Commission dated 05.12.2018 N. 96 "On the requirements for the creation, development and operation of a cross-border space of trust" (together with the "Regulations on the Commission for checking the components of the common infrastructure for documenting information in electronic form for compliance with the requirements for the creation, development, and operation cross-border space of trust ")

- The concept I use in interstate information service interactions and legally binding electronic documents, approved by the Board of the Eurasian Economic Commission dated September 18, 2014 N 73, Strategy for development of transboundary space of trust, approved 
by the decision of the Board of the Eurasian Economic Commission on September 27, $2016 \mathrm{~N}$ 105 ,

- Regulation on the exchange of electronic documents with cross-border interaction of bodies of state power of the states - members of the Eurasian economic union among themselves and with the Eurasian Economic Commission, the approval of th decision of the Board of the Eurasian Economic Commission on September 28, 2015 № 125, as well as other acts of the Commission on the establishment, development and functioning of the cross-border space of trust.

The development of common digital spaces can be considered a matter of time.

One of the main applications of digital technologies can be considered the sphere of investments $[5,6]$.

The digitalization of interactions between participants in economic relations, directly and indirectly, impacts the state and region's investment climate and investment attractiveness.

The position of a constituent entity of the Russian Federation in the National rating of the state of the investment climate in constituent entities of the Russian Federation [7,8] is determined in four areas, including the regulatory environment, institutions for business, infrastructure, and resources, support for small businesses. In turn, the quality of the regulatory environment is determined by the speed of the provision of public services. Thanks to active digitalization, the regions managed to raise their positions in this rating. Thus, digitalization allows getting rid of administrative barriers that reduce investment attractiveness.

The investment climate is also affected by the level of corruption, digitalization, and the creation of trust spaces, making it possible to minimize face-to-face interactions of economic entities with representatives of government authorities.

Digital transformation will also provide a return on investment, which should attract longterm foreign investment.

Conclusion

However, one should not forget that digitalization is only a tool, an investment infrastructure element that cannot replace real business processes. Therefore, promising longterm investment proposals and projects should become the most important base of investment attractiveness.

\section{References}

1. Домрачев А. Формирование единых региональных цифровых пространств с использованием трансграничного пространства доверия. [Электронный ресурс] URL: https://clck.ru/RxhAb (дата обращения 02.10.2020)

2. Электронное взаимодействие. Юридически значимые аспекты - СПб., 2016.

[Электронный ресурc] URL: https://clck.ru/RxhAy (дата обращения 05.02.2019)

3. Вайпан В. А. Основы правового регулирования цифровой экономики // [Электронный pecypc] URL: http://отрасли-права.pф/article/26874 (дата обращения 20.02.2019)

4. Белая книга о надежной трансграничной среде. Обеспечение юридически значимого надежного трансграничного электронного взаимодействия ЕЭК, Центр ООН по упрощению процедур торговли и электронным деловым операциям СЕФАКТ, 30 апреля - 1 мая 2018.

5. Shpinev Iu.S. On the issue of defining the concept of investment in law and science // Modern Science. - 2020. - № 6-1. - C. 245-251.

6. Shpinev Iu.S. Classification of investments // Modern Science. - 2020. - № 6-1. - C. 251-256. 
7. Официальный сайт Агентства стратегических инициатив. [Электронный ресурc] URL: https://asi.ru/government_officials/rating/ (дата обращения 11.11.2020)

8. Овчинникова Ю.С. Право собственности и другие вещные права в юридической науке, законодательстве и практике России и зарубежных стран: материалы конференции // Государство и право. - 1999. - № 11. - С. 80-89. 